\title{
Translational research: what is the value of experimental studies in comparison with clinical studies to help understand clinical problems?
}

\author{
Paolo Cinelli ${ }^{1} \cdot$ Katrin Rauen ${ }^{2} \cdot$ Sascha Halvazishadeh ${ }^{1} \cdot$ Hans Christoph Pape $^{1}$
}

Published online: 12 September 2018

○) Springer-Verlag GmbH Germany, part of Springer Nature 2018

\begin{abstract}
Along with the development of sophisticated methods to assess parameters in experimental animal and laboratory studies, the meaningfulness of these studies has increased. Clinical studies alone may be difficult to obtain $[1,2]$ and patient numbers may represent an issue [3]. This may get to a point where research organizations stop providing the financial support if the patient numbers are not met on time [4]. Other publications provide subsets of data studies that may suffer from type II errors and lack of long-term impact [5, 6] (Table 1).
\end{abstract}

Therefore, approaches from 'bench to bedside' have been emphasized. They are thought to facilitate the gathering of knowledge, allow to be more cost effective and provide rapid results [7]. Animal studies are more standardized, whenever a standardized model is available. Until the late 1990s, sophisticated methods to study the impact of trauma on an organism mimicking the human situation was merely possible using primates [8].

Translation in the field of traumatic brain injury (TBI) seems to be especially challenging, most probably due to (I) the heterogenous TBI population in clinical trials, (II) the necessity of an appropriate TBI severity classification beyond the initial Glasgow Coma Scale, (III) suitable outcome parameters, and finally (IV) the problem of choosing the right experimental TBI model.

It is well known that TBI is still the most common cause of disability and mortality in industrialized countries and even more prevalent than stroke. But in contrast to stroke, TBI mainly affects the young and working populations,

Hans Christoph Pape

Hans-Christoph.Pape@usz.ch

1 Department of Trauma, Universitaetsspital Zurich, Raemistrasse 100, 8091 Zurich, Switzerland

2 Institute for Regenerative Medicine, IREM, University of Zurich, Campus Schlieren, Wagistrasse 12, Schlieren, 8952 Zurich, Switzerland thereby causing tremendous personnel and socio-economic burdens that underline the need for neuroprotective and causal treatment targeting the secondary brain injury cascades and the sequels of chronic traumatic encephalopathy. Thus, TBI is a silent epidemic resulting in diverse neuropsychiatric long-term sequels including behavioral and cognitive deficits [9].

Since Klatzko brought up the concept of vasogenic and cytotoxic brain edema, experimental TBI research successfully elucidated the histopathological and molecular changes of the secondary brain injury cascade following TBI [10]. However, more than three decades of experimental TBI research brought up promising neuroprotective compounds-primarily targeting secondary brain edema and raised intracranial pressure (ICP) including inflammation, oxidative stress, excitotoxicity, mitochondrial dysfunction, cell death and blood-brain-barrier disruption-that unfortunately failed in more than 30 clinical trials $[11,12]$. As mentioned, translation in the field of TBI is challenging and well-established experimental and primarily rodent TBI models that mainly mimic focal or mixed closed brain injury need to be reassessed [13]. Furthermore, new concepts of multipotential approaches in rodents and gyrencephalic species according to the STAIR criteria — known from translational stroke research-are crucial [14]. Certainly, long-term outcome studies might help to further elucidate the chronic sequels of traumatic encephalopathy and might help to better classify TBI for clinical and research purposes.

Whenever the cardiovascular system was to be studied, sheep or dog models were used, but none of them provided results of inflammatory parameters or other clinically relevant results $[15,16]$. To mimic results of surgical procedures, systemic parameters were difficult to obtain and secondary parameters were utilized [17]. The current issues provide examples from a scientifically active and ongoing group named TREAT [18]. This group has been working in multiple research centers, such as Vienna, 
Table 1 Documentation of recruitment conditions in clinical studies dealing with trauma patients

\begin{tabular}{llllll}
\hline References & $n$ (pat.) & $\begin{array}{l}\text { Study } \\
\text { duration } \\
\text { (years) }\end{array}$ & $\begin{array}{l}\text { Inclu- } \\
\text { sion } \\
\text { criteria }\end{array}$ & $\begin{array}{l}\text { Power } \\
\text { analysis }\end{array}$ & $\begin{array}{l}\text { No. of } \\
\text { centers }\end{array}$ \\
\hline$[4]$ & 34 & 2.5 & $4^{\mathrm{b}}$ & - & $>10$ \\
{$[2]$} & 165 & 6 & $3^{\mathrm{a}}$ & 150 & 10 \\
\hline
\end{tabular}

Inclusion criteria in detail

${ }^{a}$ New injury severity score $\geq 16$ points, or three fractures and abbreviated injury scale score. 2 points and another injury (abbreviated injury scale score 2 points), and age 18-65 years

${ }^{b}$ Injury of at least two body regions with an injury severity score (ISS) $\geq 16$, a femoral shaft fracture which can be treated in principle by nail or fixateur externe (surgical treatment beginning within $24 \mathrm{~h}$ after trauma), age $\geq 18$ years, and a calculated probability of death between 20 and $60 \%$

Marburg, Aachen, Ulm, Frankfurt, Utrecht and Zurich [19-21]. The unique feature of this group is a cooperative effort of multiple researchers that have shared the burden of gathering data along with the results of their cooperation. It hopefully will serve as a role model for research cooperations in multiple places in the future.

In this FOCUS ON issue, four translational research papers are included.

The manuscript of Verboket/Marzi et al. [22] demonstrates how stem cell therapy for bone defects could be developed from cell cultures via animal experiments to a phase 2 clinical study within a few years. The requirements and hurdles for such a process are very nicely described in this story. The authors mention how they managed to develop cell lines that yield the way into a multi-center, three-arm, prospective clinical study, e.g. the perfect way of performing medicine from bench to bedside.

The review by Greven et al. [23] summarizes the current evidence of the involvements of neutrophils in the pathogenetic changes after trauma. There is an ongoing body of literature that supports the translational aspects of trauma care.

Qiao et al. [24] performed a systematic review and metaanalysis on the relevance of proinflammatory cytokines, such as interleukins. They reconfirm the meaningfulness of inflammatory changes in trauma research. The authors conclude that they continue to be of importance.

Kalbas et al. [25] used the TREAT animal model and performed studies on microcirculatory changes during and after intra- versus extramedullary instrumentation in an established pig model. Their results reconfirm the importance of studying pathogenetic changed in controlled experimental conditions that resemble the human situation.

\section{Compliance with ethical standards}

Conflict of interest All Authors declare that they have no conflict of interest.

\section{References}

1. Pape H-C, Oestern HJ, Leenen L, Yates DW, Stalp M, Grimme K, Tscherne H, Krettek C; the German Polytrauma Study Group. Documentation of blunt trauma in Europe. Eur J Trauma 2000; 26(5): 233-47.

2. Pape HC, Rixen D, Morley J, Husebye EE, Mueller M, Dumont C, Gruner A, Oestern HJ, Bayeff-Filoff M, Garving C, Pardini D, van Griensven M, Krettek C, Giannoudis P; EPOFF Study Group. Impact of the method of initial stabilization for femoral shaft fractures in patients with multiple injuries at risk for complications (borderline patients). Ann Surg. 2007;246(3):491-9 (discussion 499-501).

3. Childs B, Verhotz DR, Moore TA, Vallier H. Presentation coagulopathy and persistent acidosis predict complications in orthopaedic trauma patients. J Orthop Trauma. 2017;31(12):617-23. https ://doi.org/10.1097/BOT.0000000000000957.

4. Steinhausen E, Bouillon B, Rixen D. Members of the damage control study group. Are large fracture trials really possible? What we have learned from the randomized controlled damage control study? Eur J Trauma Emerg Surg. 2017. https://doi.org/10.1007/ s00068-017-0891-6.

5. Trentzsch H, Piltz S, Täger G, Berger F, Steinhausen E, Neugebauer EA, Rixen D; Die Mitglieder der Damage Control Study. Review. German. Randomized clinical trials in trauma surgery: decision-making in an area of conflict between eminence and evidence. Unfallchirurg. 2009;112(8):742-8. https://doi.org/10.1007/ s00113-009-1661-7.

6. Dienstknecht T, Rixen D, Giannoudis P, Pape HC; the EPOFF Study Group. Parameters used to clear noncritically injured polytrauma patients for extremity surgery predict complications? Clin Orthop Relat Res. 2013;471(9):2878-2884. https://doi. org/10.1007/s11999-013-2924-8.

7. Redl H, Schlag G, Lamche H. TNF- and LPS-induced changes of lung vascular permeability: studies in unanesthetised sheep. Circ Shock. 1990;31(2):183-92.

8. Redl H, Schlag G, Schiesser A, Davies J. Thrombomodulin release in baboon sepsis: its dependence on the dose of Escherichia coli and the presence of tumor necrosis factor. J Infect Dis. 1995;171(6):1522-7.

9. Corrigan JD, Selassie AW, Orman JA. The epidemiology of traumatic brain injury. J Head Trauma Rehabil. 2010;25:72-80.

10. Klatzo I. Presidental address. Neuropathological aspects of brain edema. J Neuropathol Exp Neurol. 1967;26:1-14.

11. Loane DJ, Faden AI. Neuroprotection for traumatic brain injury: translational challenges and emerging therapeutic strategies. Trends Pharmacol Sci. 2010;31:596-604.

12. Kabadi SV, Faden AI. Neuroprotective strategies for traumatic brain injury: improving clinical translation. Int $\mathrm{J}$ Mol Sci. 2014;15:1216-36.

13. Rauen K. Experimental therapies for brain edema and raised intracranial pressure. In: Plesnila N, Badaut J, Plesnila N (eds) Brain edema: from molecular mechanisms to clinical practice. Elsevier, New York, 2017, 353-74.

14. Albert-Weissenberger C, Siren AL. Experimental traumatic brain injury. Exp Transl Stroke Med. 2010;2:16.

15. Pfeifer R, Kobbe P, Darwiche SS, Billiar TR, Pape HC. Role of hemorrhage in the induction of systemic inflammation and remote 
organ damage: analysis of combined pseudo-fracture and hemorrhagic shock. J Orthop Res. 2011;29(2):270-4.

16. Kobbe P, Vodovotz Y, Kaczorowski DJ, Mollen KP, Billiar TR, Pape HC. Patterns of cytokine release and evolution of remote organ dysfunction after bilateral femur fracture. Shock. 2008;30(1):43-47.

17. Kobbe P, Vodovotz Y, Kaczorowski DJ, Billiar TR, Pape HC. The role of fracture-associated soft tissue injury in the induction of systemic inflammation and remote organ dysfunction after bilateral femur fracture. J Orthop Trauma. 2008;22(6):385-90.

18. Kalbitz M, Schwarz S, Weber B, Bosch B, Pressmar J, Hoenes FM, Braun CK, Horst K, Simon TP, Pfeifer R, Störmann P, Hummler H, Gebhard F, Pape HC, Huber-Lang M, Hildebrand F, TREAT Research Group. Cardiac depression in pigs after multiple trauma-characterization of posttraumatic structural and functional alterations. Sci Rep. 2017;7(1):17861. https://doi. org/10.1038/s41598-017-18088-1.

19. Qiao Z, Horst K, Teuben M, Greven J, Yin L, Kalbas Y, Tolba RH, Pape HC, Hildebrand F, Pfeifer R. TREAT group. Analysis of skeletal muscle microcirculation in a porcine polytrauma model with haemorrhagic shock. J Orthop Res. 2018;36(5):1377-82. https://doi.org/10.1002/jor.23759. (epub 2018).

20. Schimunek L, Serve R, Teuben MPJ, Störmann P, Auner B, Woschek M, Pfeifer R, Horst K, Simon TP, Kalbitz M, Sturm R, Pape HC, Hildebrand F, Marzi I, Relja B. Early decreased TLR2 expression on monocytes is associated with their reduced phagocytic activity and impaired maturation in a porcine polytrauma model. PLoS One 2017;12(11):e0187404. https://doi.org/10.1371/ journal.pone.0187404.

21. Eschbach D, Horst K, Sassen M, Andruszkow J, Mohr J, Debus F, Vogt N, Steinfeldt T, Hildebrand F, Schöller K, Uhl E, Wulf H, Ruchholtz S, Pape H, Frink M. Hypothermia does not influence liver damage and function in a porcine polytrauma model. Technol Health Care 2018;26(2):209-21. https://doi.org/10.3233/ THC-171043.

22. Verboket R, Leiblein M, Seebach C, Nau C, Janko M, Bellen M, Bönig H, Henrich D, Marzi I. Autologous cell-based therapy for treatment of large bone defects: from bench to bedside. Eur J Trauma Emerg Surg. 2018. https://doi.org/10.1007/s0006 8-018-0906-y.

23. Greven J, Pfeifer R, Zhi Q, Pape HC. Update on the role of endothelial cells in trauma. Eur J Trauma Emerg Surg. 2017. https ://doi.org/10.1007/s00068-017-0812-8.

24. Qiao Z, Wang W, Yin L, Luo P, Greven J, Horst K, Hildebrand F. Using IL-6 concentrations in the first $24 \mathrm{~h}$ following trauma to predict immunological complications and mortality in trauma patients: a meta-analysis. Eur J Trauma Emerg Surg. 2017. https ://doi.org/10.1007/s00068-017-0880-9.

25. Kalbas Y, Qiao Z, Horst K, Teuben M, Tolba RH, Hildebrand F, Pape H-C, Pfeifer R; TREAT Research Group. Early local microcirculation is improved after intramedullary nailing in comparison to external fixation in a porcine model with a femur fracture. Eur J Trauma Emerg Surg. 2018. https://doi.org/10.1007/s0006 8-018-0991-y. 